\title{
Epistaxis as an Initial Manifestation of Juvenile Xanthogranuloma: A Case Report
}

\author{
Hye-Bin Jang, ${ }^{1}$ Nah Ihm Kim², and Hyung Chae Yang ${ }^{1}$ (D) \\ ${ }^{1}$ Departments of Otolaryngology-Head and Neck Surgery, ${ }^{2}$ Pathology, Chonnam National University Medical School and \\ Chonnam National University Hospital, Gwangju, Korea
}

\author{
코피를 주소로 내원한 연소성 황색육아종 \\ 장혜빈 ${ }^{1} \cdot$ 김나임 $^{2} \cdot$ 양형채 $^{1}$ \\ 전남대학교 의과대학 전남대학교병원 이비인후과, ${ }^{1}$ 병리과 ${ }^{2}$
}

\author{
Received November 4, 2019 \\ Revised February 19, 2020 \\ Accepted February 20, 2020 \\ Address for correspondence \\ Hyung Chae Yang, MD, PhD \\ Department of Otolaryngology- \\ Head and Neck Surgery, \\ Chonnam National University \\ Medical School and Chonnam National \\ University Hospital, 42 Jebong-ro, \\ Dong-gu, Gwangju 61469, Korea \\ Tel $+82-62-220-6776$ \\ Fax $+82-62-228-7743$ \\ E-mail blessed@jnu.ac.kr
}

Juvenile xanthogranuloma (JXG) is a rare benign histiocytic tumor, which was first described by Adamson in 1905. JXG typically presents as solitary or multiple yellow-brown skin nodules in infants, most often on the head, neck or upper trunk. Extracutaneous forms are rare and there are only several cases reported in the nasal cavity up to date. Previous cases were presented with the mass effect such as nasal obstruction. We recently experienced a pediatric patient with epistaxis and the nasal endoscopy suggested pyogenic granuloma. However, biopsy of the mass revealed JXG. Herein, we report a case of disseminated juvenile xanthoma misdiagnosed as pyogenic granuloma.

Korean J Otorhinolaryngol-Head Neck Surg 2021;64(2):114-8

Key Words Epistaxis · Juvenile xanthogranuloma $\cdot$ Nasal cavity Non-Langerhans-cell histiocytosis $\cdot$ Turbinate.

\section{서 론}

연소성 황색육아종은 주로 유아 및 소아에서 발견되는 양 성 종양으로, 1905년 Adamson에 의해 최초로 기술되었으며, 당시 선천성 다형성 황색육아종으로 보고되었다. ${ }^{1)}$ 호발 부위 는 머리와 목 그리고 상반신이며, ${ }^{2)}$ 이는 흔히 2세 이하에서 한 개의 홍색 혹은 황색의 피부 구진 및 결절의 형태로 나타 난다. 드물게 이러한 피부 병변이 다발성으로 나타날 수 있으 며, 황색 육아종 증례 중 $5 \%$ 에서 피부 이외의 곳에 나타나는 것으로 알려져 있다. ${ }^{3)}$ 특히 두경부에 발생한 황색육아종은 매우 드문 편이며, 비강 내에 발생한 황색육아종은 국외 6 증 례, 국내 2 증례에 불과하다. 화농성 육아종이나 혈관종과 유 사한 형태를 띄지만, 전신에 동시다발적인 발현을 보일수 있

This is an Open Access article distributed under the terms of the Creative Commons Attribution Non-Commercial License (https://creativecommons.org/licenses/by-nc/4.0) which permits unrestricted non-commercial use, distribution, and reproduction in any medium, provided the original work is properly cited.
는 적극적인 치료가 필요한 질환이다. 현재까지 보고된 황색 육아종 환자들은 모두 비폐색, 혹은 우연히 발견된 비전정 종물 등 덩이효과(mass effect)에 의한 증상을 주소로 발견 되었으며, 아직 비출혈의 원인으로 보고된 증례는 없다. 이에 본 저자들은 본 증례보고를 통해, 비출혈을 주소로 내원하여 시행한 이학적 검사상 화농성 육아종이 의심되었던 환자에 서 연소성 육아종으로 진단되고, 이후 발견된 전신 병변에 대 해 추가 치료를 시행한 환자의 증례를 공유하고자한다.

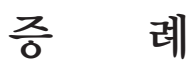

2세 여아가 5개월전부터 반복되는 좌측 비출혈을 주소로 내원하였다. 비내시경(nasopharyngoscopy)을 통한 이학적 검 사상 좌측 하비갑개의 후측에 직하방으로 붙어있는 종물(Fig. $1 \mathrm{~A})$ 이 관찰되었다. 육안 소견 상 경계가 매끄러운 황색 구형 종물로, 소아 및 성인의 비종물 중 흔히 관찰되는 화농성 육 
아종(pyogenic granuloma)으로 사료되었으며, 이에 추가적인 평가를 위해 조영증강 부비동 전산화단층촬영(PNS CT enhance)을 시행하였다. 시행한 위 영상검사 상에서 양측 하비 도를 차지하고 있는 종물이 관찰되었다. 이들은 $1 \mathrm{~cm}$ 크기의 조영증강 되지 않으며 하운스필드단위(hounsfield unit)가 균 질한(homogenous)한 용종과 유사한 소견(Fig. 1B)을 보였다. 양측 상악동 및 사골동의 혼탁 소견 또한 함께 관찰되었다.

이에 반복적인 비출혈의 교정과 조직학적 검사를 위해 내시 경하 종물 절제술(endoscopic nasal cavity mass removal)을 시행하였다. 수술 소견 상, 하비갑개 후측에 직경 약 $1 \mathrm{~cm}$ 의 황색을 띠는 종물이 양측에서 각각 관찰되었으며 종물 주변 에는 장액성 분비물 외에 특이 소견은 관찰되지 않았으나, 양
측 모두 종물의 기원이 가측 비벽에 있는 비전형적 병변으로 관찰되었다. 양측 비강 내 종물은 내시경적 접근을 통해 육안 적으로 모두 제거하였고, 이후 비 출혈 증상은 호전되었다.

이후 최종 진단을 위한 병리 조직 검사를 확인한 결과, 육안 소견 상에서 의심된 화농성 육아종과 다른 병리소견을 보였 다. 연소성 황색 육아종에서 특징적으로 관찰되는 투톤 거대 세포(touton giant cell)가 관찰되었으며, 면역 염색 중 $\mathrm{Ki}-67$ 및 $\mathrm{CD}$ 68에서 양성 소견을 보였다. 이에 따라 진단명은 화농 성 육아종 의증에서 연소성 황색육아종으로 다시 내려지게 되었으며, 질환의 특징에 따라 전신 이학적 검사를 시행하였 으며, 좌측 엉덩이, 우측 허벅지 및 우측 팔에 각각 $0.5 \times 0.5$, $1 \times 1$ 및 $1 \times 1 \mathrm{~cm}$ 크기의 종물이 발견되어, 본원 성형외과에 의
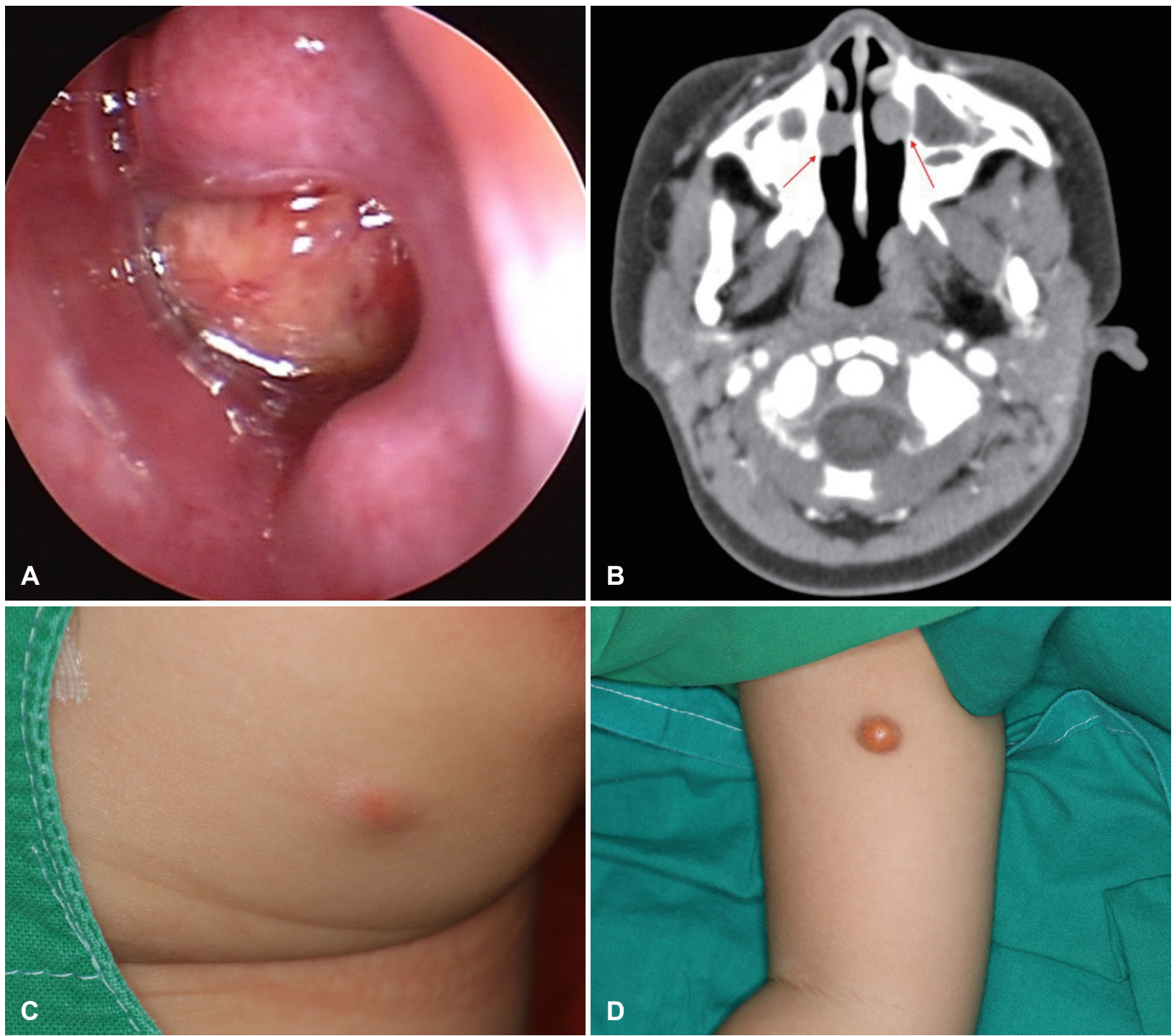

Fig. 1. A yellowish mass was found in the inferior meatus of the left nasal cavity. Note that blood oozing on the surface of yellowish mass (A). On axial computed tomography revealed that $1 \mathrm{~cm}$ sized round homogenous masses in both inferior meatus of nasal cavities (B, arrow). Result of looking gneralized skin, $1-2 \mathrm{~cm}$ sized yellowish mass was found at left buttock (C), and right upper arm (D). 
뢰 피부 종물 절제술(skin mass excision)을 시행하였다.

병리조직학적 소견상 조직구 증식과 함께 염증세포의 침 윤이 관찰되었고, 종양 세포는 작고 타원형이며 풍부한 호산 구성 세포질을 가지고 있었으며, Touton 거대 세포가 다수 관찰되었다(Fig. 2A and B). 면역조직화학 염색 상, 두 조직 에서 모두 조직구 표지자인 CD68과 CD163에 양성 소견을 보였으며(Fig. $2 \mathrm{C}$ ), 다른 질환과의 감별을 위해 실시한 CDla, Langerin에서는 음성 소견을 보였다(Fig. 2D). 이에 비강 내 종물과 피부 종물을 파종성 연소성 황색육아종으로 진단하 였다.

\section{고 찰}

연소성 황색육아종은 주로 영아기 및 유년기에 발생하는 매우 드문 조직구의 이상증식과 연관된 질환이다. 환자의 $1 / 3$ 에서는 태어날 때부터 피부 병변이 존재하며, 일반적으로
발생한 후 더 진행하지 않고 안정적인 상태로 유지되거나 자 연 퇴행하는 특징이 있으나, 일부에서는 20세 이후까지 병변 이 진행하는 경우도 있다. 가족력은 없으며 지질이상대사와 관련이 없이 발생하는것으로 알려져 있다. ${ }^{4)}$ 조직병리학적으 로는 비랑거한스 조직구성 질환(non-Langerhans cell histiocytosis)으로 주로 피부에 독립된 혹은 다발성의 융기된 병변이 발생하며 피부 병변의 색은 황갈색에서 붉은색까지 다양하며 크기 역시 매우 다양하게 존재한다. ${ }^{5}$

전체 환아의 약 $5 \%$ 에서 피부 병변 외에 전신의 장기를 침 범하는데 가장 많은 장기는 안구이며 폐가 그 다음을 차지하 고, 그 외 드물게 침범하는 장기로는 중추신경계, 간, 비장, 심장, 고환, 근육, 혀 등이 있다. 따라서 전신성 연소성 황색 육아종을 선별검사를 하기 위하여 뇌 컴퓨터 단층촬영 (Brain CT) 또는 자기공명영상(MRI), 흥부 단순 X선(chest $\mathrm{X}$-ray), 복부 초음파(Abdomen ultrasound) 또는 컴퓨터 단층촬영(abdomen $\mathrm{CT}$ ), 심초음파(echocardiography), 안구

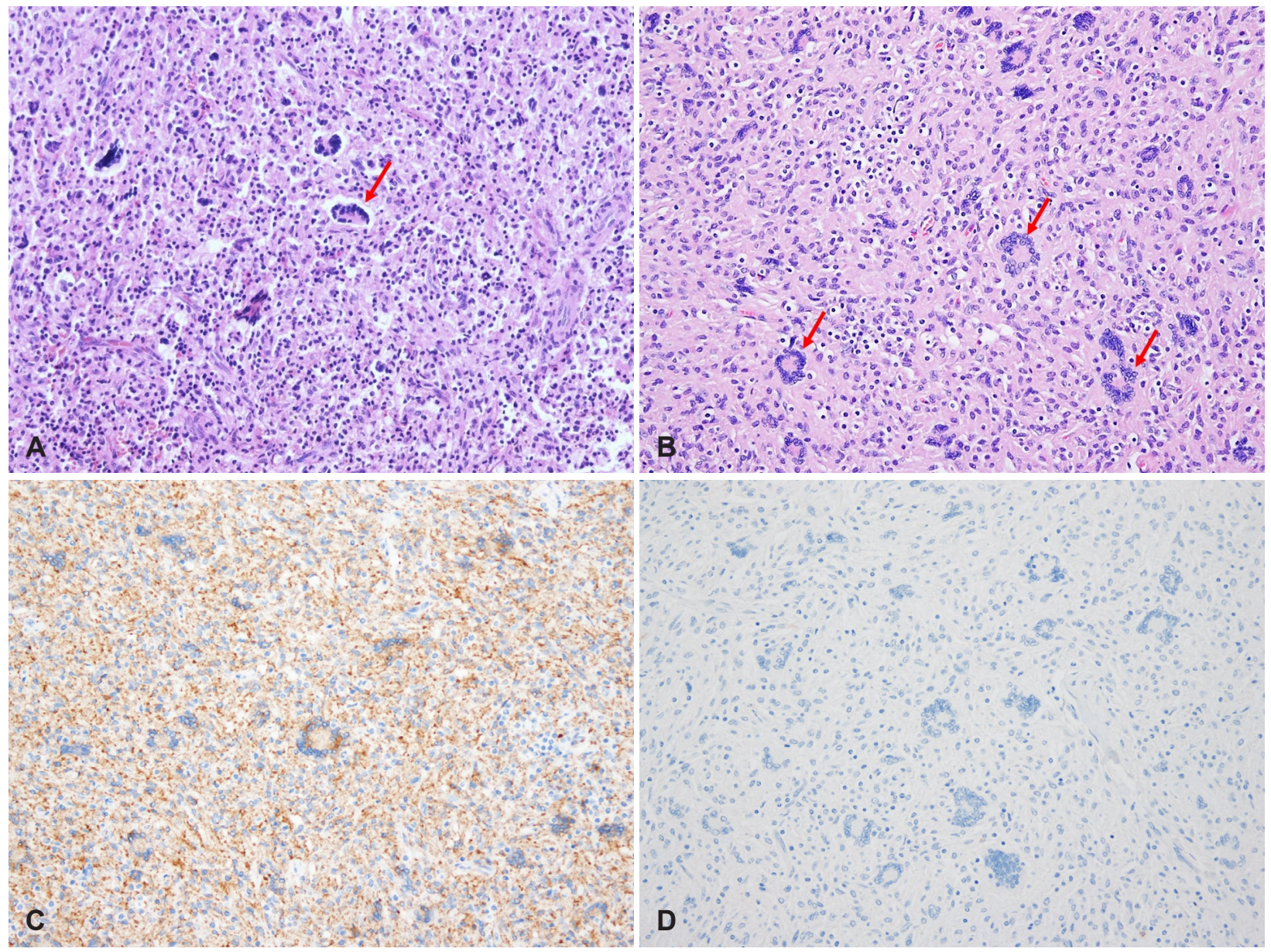

Fig. 2. The biopsy specimen of the nasal cavity $(A)$ and skin $(B)$ show dense histiocytic proliferation and mixed infiltrate of numerous Touton giant cells (arrows) (Hematoxylin \& eosin, $\times 200$ ). Immunohistochemistry showed expression of CD68 (C), but lack of CD1a expression (D) $(\times 200)$. 
검사(eye examination) 등이 필요하다. ${ }^{6}$

진단을 위해서는 병변의 조직검사가 반드시 선행되어야 한 다. 조직병리검사에서는 초기 병변과 성숙기 병변에서 차이 가 나타나게 되는데, 초기 병변에서는 지질을 함유하지 않는 조직구가 소수의 림프구, 호산구 등의 염증세포의 침윤이 동 반되며, 성숙기 병변에서는 포말세포, 투톤 거대세포 등이 조 직구, 림프구 및 소수의 호산구와 함께 육아종성 침윤을 보 인다. 투톤 거대 세포는 중심부에 화관 모양의 핵들과 주변 부의 호산성 또는 공포화된 세포질로 이루어진 세포를 말하 며 피부 병변에서는 거의 일정하게 나타나고 피부 외 병변인 경우 적은 수로 나타나거나 없는 경우도 있다. ${ }^{7)}$ 본 증례에서 는 비출혈을 야기하는 비강내 종물로 내시경 소견상으로는 화농성 육아종이 의심되었지만, 현미경적 소견을 보았을 때 혈관 이형성 혹은 혈관 증식과 같은 출혈을 야기할 수 있는 소견이 관찰되지 않았다. 또한, 조직구 증식과 함께 염증세포 의 침윤이 관찰되었고, 종양 세포는 작고 타원형이며 풍부한 호산구성 세포질을 가지고 있었으며, 투톤 거대 세포가 다수 관찰되었다. 그외 유사분열이나 괴사, 출혈의 소견은 보이지 않았다. 따라서 본 증례의 경우 조직학적으로 연소성 육아종 성숙기 병변으로 판단되었다.

연소성 황색 육아종의 경우, 피부 및 연조직에서 특징적으 로 관찰되지만 파종성 형태는 일반적으로 점막 표면에 호발 하며 상부 호흡기 및 소화관에도 발생할 수 있다. 유소아에 서 발생한 경우 대부분 약간의 색소 침착과 위축만을 남길 뿐 자연관해되는 경우가 많고, 내부 장기 병변도 같이 소실 되므로 다른 수술적인 처치나 다른 치료가 필요하지는 않 다. ${ }^{8)}$ 그러나 진단 혹은 미용적인 목적으로 절제술이 필요할 수 있으며, 중추신경계, 심근막 등의 주요 장기의 병변에 침 범한 경우나 안구에 침범한 경우 항암치료나 방사선 치료가 필요할 때가 있다. ${ }^{9)}$ 또한 매우 드물게 대식세포 활성화 증후 군이 수반되는 경우에는 혈소판 감소증을 유발할 수 있다고 알려져 있다. 본 환자의 경우 헤모글로빈과 혈소판 수치 모두 정상 소견을 보였으며, 이에 혈액학적 질환에 대한 가능성을 배제할 수 있었다.

환자들은 다발성종물을 주소로 병원에 내원하는 경우가 대부분이다. 문헌검색이 가능한 총 8예 중 종물에 의한 비폐 색을 유발하여 내원한 경우가 4예 있으며, ${ }^{10-13)}$ 비강내 전정부 위의 종물이 관찰되어 내원한 경우가 4예 있었다. ${ }^{14-17)}$ 하지 만, 본 증례의 경우처럼 비출혈을 주소로 내원한 환자에서 진단된 증례는 없었다. 본 증례의 경우, 황색육아종이 가측 비강벽에서 기원하여 하비갑개에 막혀 하비도로 돌출되지 못했고, 비전방이 아닌 비강의 중간부위에 위치해 있어, 비출 혈을 야기한 후에야 인지될 수 있었던 것으로 생각된다.
본 황색육아종 증례 환자는 간헐적인 일측 비출혈을 주소 로 내원하였으며, 최초 시행한 이학적 검사상 관찰된 연분홍 색의 경계가 좋은 종물(smooth margined mass)로 술자들에 게 화농성 육아종을 의심케 하였지만, 조직검사 결과 연소성 육아종으로 판단되었다. 이후 추가적인 검사 및 평가를 통해 다발성 연소성 황색육아종(disseminated juvenile xanthogranuloma)을 진단받았던 증례이다. 하지만, 황색육아종의 경우 화농성 육아종과 달리, 안구, 중추신경계, 간, 비장, 심 장, 고환, 근육, 다양한 기관에 동시다발적으로 발생할 수 있 고, 단순 소작술을 통한 제거가 아닌 병변 부위에 따른 적절 한 치료가 필요한 질환이다. 진단에 따라 치료법이 달라질 수 있기 때문에 코피를 주소로 내원한 소아환자의 경우, 전형적 인 화농성 중이염의 임상 소견을 보이더라도 반드시 조직검 사를 통한 확진이 필요함을 시사하는 증례라 볼 수 있다.

연소성 육아종은 일반적으로 종물의 형태를 주소로 내원 하여 진단되는 것으로 알려져 있다. 하지만, 비강내 연소 육 아종의 경우 본 증례 환자의 경우처럼 비출혈을 주소로 내원 할 수 있으며, 이런 경우 임상적으로 화농성 육아종으로 오 인될 수 있다. 연소성 육아종, 특히 파종성 연소성 육아종의 경우 다양한 장기에 다발적으로 발생할 수 있고, 이에 대한 평가와 치료가 필요한 질환이다. 따라서 조직검사를 통한 확 진 및 필요시 영상의학적 검사등을 통한 평가가 이루어져야 할 것으로 생각된다.

\section{Acknowledgments}

This research was supported by Basic Science Research Program through the National Research Foundation of Korea (NRF) funded by the Ministry of Education (NRF-2018R1D1A1B07046906) and a grant (BCRI-18020) of Chonnam National University Hospital Biomedical Research Institute.

Ethics approval: All procedures involving human subjects were performed in accordance with the ethical standards of our institutional and/or national research committee and the 1964 Helsinki declaration and later amendments thereof, or comparable ethical standards (IRB no. CNUH-EXP-2019-308).

Some parts of this study were presented at the KORL-HNS conference 2019, Korea, 16-17 October, 2019.

\section{Author Contribution}

Conceptualization: Hyung Chae Yang. Data curation: Hye-Bin Jang. Formal analysis: Hye-Bin Jang. Funding acquisition: Hyung Chae Yang. Investigation: Hyung Chae Yang. Methodology: Nah Ihm Kim. Project administration: Hyung Chae Yang. Resources: Hyung Chae Yang. Software: Nah Ihm Kim. Supervision: Hyung Chae Yang. Validation: Nah Ihm Kim. Visualization: Hye-Bin Jang. Writing — original draft: Hye-Bin Jang. Writing — review \& editing: Hyung Chae Yang, Nah Ihm Kim.

\section{ORCID}

Hyung Chae Yang https://orcid.org/0000-0002-9187-1367 


\section{REFERENCES}

1) James WD. A case of congenital xanthoma multiplex. Br Med J 1894;2(1763):805.

2) Tahan SR, Pastel-Levy C, Bhan AK, Mihm MC Jr. Juvenile xanthogranuloma. Clinical and pathologic characterization. Arch Pathol Lab Med 1989;113(9):1057-61.

3) Chung BJ, Embi CS, Sellheyer K, Krakovitz PR. Pathology quiz case. Nasal juvenile xanthogranuloma (JXG). Arch Otolaryngol Head Neck Surg 2005;131(1):81; diagnosis 82.

4) Goldblum JR, Weiss SW, Folpe AL. Enzinger and Weiss's soft tissue tumors. 6th ed. Philadelphia, PA: Elsevier Saunders;2014.

5) Flaitz C, Allen C, Neville B, Hicks J. Juvenile xanthogranuloma of the oral cavity in children: A clinicopathologic study. Oral Surg Oral Med Oral Pathol Oral Radiol Endod 2002;94(3):345-52.

6) Freyer DR, Kennedy R, Bostrom BC, Kohut G, Dehner LP. Juvenile xanthogranuloma: Forms of systemic disease and their clinical implications. J Pediatr 1996;129(2):227-37.

7) Kraus MD, Haley JC, Ruiz R, Essary L, Moran CA, Fletcher CD. "Juvenile" xanthogranuloma: An immunophenotypic study with a reappraisal of histogenesis. Am J Dermatopathol 2001;23(2):104-11.

8) Chang MW. Update on juvenile xanthogranuloma: Unusual cutaneous and systemic variants. Semin Cutan Med Surg 1999;18(3):195-205.

9) Webster SB, Reister HC, Harman LE Jr. Juvenile xanthogranuloma with extracutaneous lesions. A case report and review of the literature. Arch Dermatol 1966;93(1):71-6.

10) Suh SH, Son JY, Kim BM, Kim CK, Je JS. A Case of the Juvenile Xanthogranuloma of the Nasal Cavity and Testis. Korean J Otolaryngol-Head Neck Surg 2001;44(9):997-1000.

11) Saravanappa N, Rashid AM, Thebe PR, Davis JP. Juvenile xanthogranuloma of the nasal cavity. J Laryngol Otol 2000;114(6): 460-1.

12) Avelino MGA, Pereira FC, Moreira KXR, Fujita RR, Stamm AEC, Weckx LLM. Xantogranuloma juvenil em cavidade nasal. Rev Bras Otorrinolaringol 2002;68:767-9.

13) Fang TJ, Lin CZ, Li HY. Juvenile xanthogranuloma of the nasal cavity. Int J Pediatr Otorhinolaryngol 2003;67(3):297-9.

14) Kim SW, Han TY, Lee JH, Son SJ. A case of juvenile xanthogranuloma in the nasal cavity of a neonate. Indian J Dermatol 2013;58(5):411.

15) An JS, Han SH, Lee JH, Lee ES, Park HR, Kim YS. Juvenile xanthogranuloma of the nasal cavity: A case report and review of the literature. Korean J Pathol 2006;40(3):241-244.

16) Ho WL, Chan KC. Juvenile xanthogranuloma of the nasal vestibule. Ear Nose Throat J 2012;91(10):418-9.

17) Cardis M, Marathe K. Juvenile xanthogranuloma and the "setting sun”. J Am Acad Dermatol 2018;79(3 Suppl 1):AB174. 